\title{
Short-term harmful effects of unionised ammonia on natural populations of Moina micrura and Brachionus rubens in a deep waste treatment pond
}

\author{
$\underline{\text { M. Arauzo }}{ }^{\mathrm{a}}, \underline{\text { M. Valladolid }}$ \\ a \\ Madrid 28006, Spain. \\ Madrid 28006, Spain
}

, Centro de Ciencias Medioambientales C.S.I.C., Serrano 115 dpdo.,

, Museo Nacional de Ciencias Naturales C.S.I.C., José Gutiérrez Abascal 2,

\begin{abstract}
Populations of Moina micrura and Brachionus rubens in a deep waste treatment pond were exposed to the natural short-term fluctuations of unionised ammonia (90-min intervals of monitoring) that occur in the course of a day during a summer algal bloom. Under natural conditions, three replicate experiments were conducted in which water temperature, $\mathrm{pH}$, dissolved oxygen, total ammonia, unionised ammonia, phytoplankton biomass and zooplankton (number of living and dead organisms, mortality rate and instant mortality) were studied. The timecourse of unionised ammonia concentration was consistent with those shown by temperature, $\mathrm{pH}$, phytoplankton biomass, dissolved oxygen, Moina micrura mortality and Brachionus rubens mortality. On the other hand, temperature, $\mathrm{pH}$ and dissolved oxygen never exceeded the tolerance ranges described for Moina and Brachionus, which led us to attribute the cause of zooplankton mortality to unionised ammonia toxicity. Mortality rates of $63 \%$, $27 \%$ and $34 \%$ were recorded for Moina in each replicate experiment. Brachionus was less affected, with mortalities of $7.3 \%, 6.2 \%$ and $6.0 \%$.
\end{abstract}

These results confirm previous field observations (Water Res. 34(14) (2000) 3666; Water Res. 37(5) (2003) 1048) that attributed a reduction in zooplankton biomass during certain periods of summer (algal blooms) to a harmful sideeffect of an excessive increase in phytoplankton biomass: high photosynthetic activity during these periods of proliferation of algae gives rise to an increased $\mathrm{pH}(\square 8)$ and, subsequently, leads to production of unionised ammonia (toxic for aquatic organisms) from its ionised fraction.

KEYWORDS: UNIONISED AMMONIA; BRACHIONUS RUBENS; MOINA MICRURA; DEEP WASTE TREATMENT POND

\section{INTRODUCTION}

There are numerous reports on the harmful effects of unionised ammonia on aquatic organisms [1], [2], [3], [4], [5], [6], [7], [8] and [9] but its effects on plankton communities in waste treatment ponds and its negative influence on the pond performance have been scarcely investigated [10] and [11].

In aqueous solutions, unionised ammonia $\left(\mathrm{NH}_{3}\right)$ is in equilibrium with ionised ammonia $\left(\mathrm{NH}_{4}{ }^{+}\right)$. This equilibrium is controlled by $\mathrm{pH}$ and temperature: as $\mathrm{pH}$ and temperature increase, the ionic form decreases and the balance shifts towards the unionised species. In eutrophic and hypereutrophic environments, this type of chemical dynamics plays a key role in ammonia toxicity, because unionised ammonia is more toxic than the ammonium ion [1], [9] and [12]. Short-term variations in pH over a day at productive depths of lenitic ecosystems are associated mostly with the photosynthetic activity of phytoplankton, which affects the carbon dioxide/carbonate equilibrium. A sine-wave pattern is frequently generated, with a minimum $\mathrm{pH}$ value just before dawn and a daily maximum in the late afternoon [12] and [13]. The effect of these intradaily changes in $\mathrm{pH}$ on aqueous ammonia equilibrium might imply intense stress for organisms in highly productive aquatic ecosystems.

A study on short-term dynamics of a natural plankton community exposed to a high concentration of unionised ammonia in a deep waste treatment pond has been carried out. The pond was designed to 
improve the quality of wastewater to be reused for agricultural irrigation. During previous studies on a longer time-scale [10] and [11], a hypothesis to explain the relationships between unionised ammonia and phytoplankton and zooplankton dynamics during the summer algal blooms was formulated: intense photosynthetic activity associated with a phytoplankton bloom causes the $\mathrm{pH}$ to rise above 8; due to this $\mathrm{pH}$ rise in an environment of high ammonia concentration and a concomitant rising temperature, unionised ammonia levels increase at the expense of the ionised fraction [1]. According to these processes, significant reductions in zooplankton biomass occurred and a diminished purification efficiency of the pond associated with this occasional destabilized trophic structure was observed [11] and [14]. It was found that phytoplankton was the main factor responsible for the $\mathrm{pH}$ rise and, ultimately, for the increase in unionised ammonia.

During the present study, the plankton community of the treatment pond was exposed to the natural short-term fluctuations of unionised ammonia that occur in the course of a day. The objective was to observe the plankton responses on a short time-scale (90-min intervals of monitoring), which was considered to be more consistent with real plankton dynamics and environmental fluctuations than longer time-scales. The assay was performed when a summer algal bloom of Oocystis pusilla Hansg. 1890 was negatively affecting the purification efficiency of the pond. Moina micrura Kurz 1874 and Brachionus rubens Ehrb. 1838 were the most abundant species in the zooplankton community during the selected period. Three replicate experiments were conducted in which time-courses of water temperature, $\mathrm{pH}$, dissolved oxygen, total ammonia, unionised ammonia, phytoplankton biomass and zooplankton (number of living and dead organisms, mortality rate and instant mortality) were studied. Relationships between these variables were examined. The hypothesis previously mentioned, which attributes reductions in zooplankton populations to a side-effect of intense photosynthetic activity associated with summer phytoplankton blooms, has been explored under a short time-scale of observation.

\section{Methodology}

The waste treatment pond was $4.75 \mathrm{~m}$ deep with a volume of $2170 \mathrm{~m}^{3}$ and was continuously fed with secondary effluent from an urban wastewater treatment plant (activated sludge method) at a flow rate of $8 \pm 1 \mathrm{~m}^{3} \mathrm{~h}^{-1}$. This corresponded to a mean hydraulic retention time of $11 \pm 1$ days. The pond was constructed at Finca La Poveda (Arganda del Rey, Comunidad de Madrid, Spain) and is managed by Centro de Ciencias Medioambientales (C.S.I.C.). Its shape was an inverted truncated square pyramid, measuring $10 \times 10 \mathrm{~m}^{2}$ at the bottom and $31 \times 31 \mathrm{~m}^{2}$ at the surface. The lining material was geotextile felt, which was overlaid with a layer of high-density polyethylene to prevent leakage. Due to the depth of the pond, summer stratifications (usually from April until the beginning of September) occur, during which oxygen is absent in the metalimnion (from 1.5-2 $\mathrm{m}$ depth to the bottom), whereas the epilimnion (upper mixing layer, from the surface to 1.5-2 $\mathrm{m}$ depth) remains oxygenated. Hypoxia/anoxia in the metalimnion during stratifications is a factor that strongly limits the diel cycles of the zooplankton species that require oxygen, these being confined in the layer between the surface and 1.5$2 \mathrm{~m}$ depth [10], [11] and [14]. These constraints derived from the pond depth determined the design of the experiment.

The assay was performed on 15 July 2001. Specific environmental conditions determined the selection of this day: it was summer, the pond was stratified, a phytoplankton bloom was occurring, the epilimnion (from the surface to $1.5 \mathrm{~m}$ depth) was oxygenated, there was anoxia from $1.5 \mathrm{~m}$ depth to the bottom of the pond, most of the zooplankton populations were confined in the epilimnion and the concentration of unionised ammonia at 9:30 a.m. in the epilimnion was close to $2.5 \mathrm{mg} \mathrm{L}^{-1}$. In Arauzo [10] this value was considered the risk threshold over which zooplankton populations could be negatively affected by unionised ammonia. 
Three replicate experiments were conducted, each in an uncovered, translucent plastic container measuring $40 \times 50 \mathrm{~cm}^{2}$ at the base and $25 \mathrm{~cm}$ in depth. Twenty-five litres of water were taken from the epilimnion, immediately before the experiment, and poured into each of the three containers. To maintain the natural conditions of solar irradiance and temperature, a floating platform was constructed to support the three containers so that their water surface would be at the same level as the surface of the pond. The experimental platform was placed in the middle of the pond. There was full contact between the outside of the containers and the pond water, but there was no possibility for exchange of water and plankton between the containers and the epilimnion of the pond. The use of containers limited the advection of plankton in the epilimnion resulting, therefore, in accurate population monitoring.

The following variables were recorded at 90-min intervals from 11:00 to 20:00 h for each replicate: water temperature, dissolved oxygen, $\mathrm{pH}$, total ammonia, phytoplankton biomass and zooplankton densities of each species. To avoid the effects of any distribution pattern of the plankton inside the containers, the water was mixed immediately before plankton sampling, at each and every sampling time, in the three containers.

The density of the phytoplankton community was estimated by optical inverted microscopy [15] and biomass according to Rott [16].

The population densities of Brachionus rubens Ehrb. 1838 (Rotifera) and Moina micrura Kurz 1874 (Cladocera) were determined according to the method of Dumont et al. [17]. For total counts of individuals of each species, an aliquot was fixed in $5 \%$ formaldehyde solution. The methodology used to determine dead Moina and Brachionus specimens was based on "in vivo" immediate observations of the samples under the inverted microscope, after the settling of the dead individuals in Utermölh chambers during a period of $15 \mathrm{~min}$. Only those individuals settled on the bottom of the chambers and showing permanent lack of any movement (immobile swimming antennae and legs with filtering combs in Cladocera and immobile coronal cilia in Rotifera) were considered dead and subsequently counted. The number of living organisms was calculated by subtracting the dead from the total zooplankton count.

The mortality rate of each zooplankton population was taken as the number of dead organisms expressed as a percentage of the total number. This value is cumulative since it takes into account the number of dead organisms from the start of the experiment until each sampling time. The difference in the percentage of dead organisms between two sampling times was taken to denote "instant mortality". This value was calculated by subtracting the percentage of dead organisms corresponding to the preceding sampling time.

Temperature and oxygen were recorded using a YSI-57 dissolved oxygen field meter, and a $\mathrm{HI} 9023 \mathrm{C} \mathrm{H}$ field meter was used to monitor $\mathrm{pH}$.

The terms "ionised ammonia" and "unionised ammonia" were used to describe the two states of total ammonia $\left(\mathrm{NH}_{4}{ }^{+}, \mathrm{NH}_{3}\right)$. Total ammonia analyses were performed according to APHA [18]. Unionised ammonia was calculated from total ammonia, taking into account $\mathrm{pH}$ and temperature [1].

Statistica for Windows software (version 5.0 A [19]) was used for Pearson correlations between the variables. 


\section{RESULTS}

Fig. 1 illustrates the time-courses shown by the abiotic variables during the assay. The behaviour of each variable was similar for the three replicate experiments. Water temperature, dissolved oxygen, $\mathrm{pH}$ and unionised ammonia increased from 11:00 to 15:30 $\mathrm{h}$ and showed a small decline at the end of the experiment, whereas total ammonia decreased from beginning to end. Despite the decreasing tendency shown by total ammonia, the unionised ammonia concentration rose with increasing temperature and $\mathrm{pH}$. Mean unionised ammonia concentration with respect to total ammonia was $27 \%$ at the start of the experiment, $85 \%$ at $17: 00 \mathrm{~h}$ and $78 \%$ at the end. Significant pairwise correlations were observed among $\mathrm{pH}$, temperature, dissolved oxygen and unionised ammonia in all the replicates (Table 1). No significant differences were seen between water temperature inside the containers and in the epilimnion of the pond.
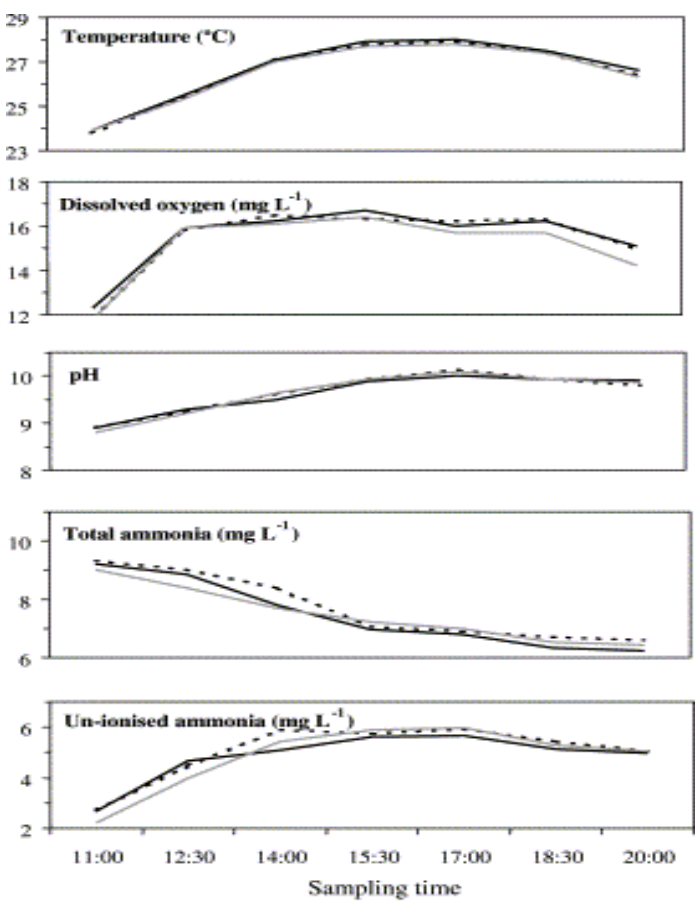

Fig. 1. \begin{tabular}{lll|}
\hline replicate 1 & $\cdots \cdot$ replicate 2 & - replicate 3 \\
\hline
\end{tabular}

Time-courses shown by temperature, dissolved oxygen, $\mathrm{pH}$, total ammonia and unionised ammonia in the three replicate experiments. 
Table 1.

Correlation matrices derived from variables monitored in the three replicate experiments

\begin{tabular}{|c|c|c|c|c|c|c|c|c|}
\hline & $\mathrm{NH}_{3}$ & $\mathrm{pH}$ & $\mathbf{T}$ & DO & Oocystis & $\begin{array}{c}\text { Moina } \\
\text { mortality }\end{array}$ & $\begin{array}{c}\text { Moina inst. } \\
\text { mortality }\end{array}$ & $\begin{array}{c}\text { Brachionus } \\
\text { mortality }\end{array}$ \\
\hline \multicolumn{9}{|l|}{ Replicate 1} \\
\hline $\mathrm{pH}$ & $0.90^{*}$ & & & & & & & \\
\hline$T$ & $0.95^{* *}$ & $0.92^{* *}$ & & & & & & \\
\hline $\mathrm{DO}$ & $0.94^{* *}$ & 0.87 *** & $0.87^{* *}$ & & & & & \\
\hline Oocystis & $0.67^{\text {**** }}$ & $0.82^{*}$ & $0.95^{* *}$ & ns & & & & \\
\hline Moina mortality & $0.87^{* *}$ & $0.91^{* *}$ & $0.96^{* * *}$ & $0.76 *$ & 0.69 ***** & & & \\
\hline $\begin{array}{l}\text { Moina inst. } \\
\text { mortality }\end{array}$ & ns & ns & ns & ns & ns & ns & & \\
\hline $\begin{array}{l}\text { Brachionus } \\
\text { mortality }\end{array}$ & $0.87^{* *}$ & $0.92^{* *}$ & $0.90 * *$ & $0.75^{*}$ & $0.81^{*}$ & $0.96 * *$ & ns & \\
\hline $\begin{array}{l}\text { Brach. inst. } \\
\text { mortality }\end{array}$ & ns & ns & ns & ns & ns & |ns & $0.90^{*}$ & ns \\
\hline \multicolumn{9}{|l|}{ Replicate 2} \\
\hline $\mathrm{pH}$ & $0.89 * *$ & & & & & & & \\
\hline$T$ & $0.97^{\text {** }}$ & $0.95^{* *}$ & & & & & & \\
\hline $\mathrm{DO}$ & $0.94^{* * *}$ & $0.76^{*}$ & $0.88^{* * *}$ & & & & & \\
\hline Oocystis & $0.88^{* *}$ & $0.95^{* *}$ & $0.94^{* *}$ & $0.80^{*}$ & & & & \\
\hline Moina mortality & $0.77^{*}$ & $0.92^{* *}$ & $0.91^{* * *}$ & $0.67^{* * * *}$ & 0.89 *** & & & \\
\hline $\begin{array}{l}\text { Moina inst. } \\
\text { mortality }\end{array}$ & ns & ns & ns & $0.85^{*}$ & ns & ns & & \\
\hline $\begin{array}{l}\text { Brachionus } \\
\text { mortality }\end{array}$ & 0.83* & $0.98^{* *}$ & $0.88 * *$ & $0.70^{* * *}$ & $0.96^{* *}$ & |0.83* & ns & \\
\hline $\begin{array}{l}\text { Brach. inst. } \\
\text { mortality }\end{array}$ & ns & ns & ns & ns & ns & ns & ns & ns \\
\hline \multicolumn{9}{|l|}{ Replicate 3} \\
\hline $\mathrm{pH}$ & $0.95^{* *}$ & & & & & & & \\
\hline
\end{tabular}




\begin{tabular}{|c|c|c|c|c|c|c|c|c|}
\hline & $\mathrm{NH}_{3}$ & pH & $T$ & DO & Oocystis & $\begin{array}{c}\text { Moina } \\
\text { mortality }\end{array}$ & $\begin{array}{c}\text { Moina inst. } \\
\text { mortality }\end{array}$ & $\begin{array}{c}\text { Brachionus } \\
\text { mortality }\end{array}$ \\
\hline$T$ & $0.98^{* *}$ & $0.95^{* * *}$ & & & & & & \\
\hline $\mathrm{DO}$ & $0.82^{*}$ & 0.67 **** & $0.80^{*}$ & & & & & \\
\hline Oocystis & $0.85^{*}$ & $0.93^{* * *}$ & $0.87^{*}$ & ns & & & & \\
\hline Moina mortality & $0.91^{\text {** }}$ & $0.94^{* * *}$ & $0.92^{* *}$ & ns & $0,86^{*}$ & & & \\
\hline $\begin{array}{l}\text { Moina inst. } \\
\text { mortality }\end{array}$ & ns & ns & ns & ns & ns & ns & & \\
\hline $\begin{array}{l}\text { Brachionus } \\
\text { mortality }\end{array}$ & $0.90^{\text {** }}$ & $0.96^{* *}$ & $0.88^{* *} \mid$ & ns & $0.96^{* *}$ & $0.88^{* *}$ & ns & \\
\hline $\begin{array}{l}\text { Brach. inst. } \\
\text { mortality }\end{array}$ & ns & ns & ns & ns & ns & ns & ns & ns \\
\hline
\end{tabular}

ns: Non-significant. $n=7$, except for instant mortality of Moina micrura and Brachionus rubens, where $n=6$.

T: water temperature. DO: dissolved oxygen. Oocystis: Oocystis pusilla biomass. Moina mortality: Moina micrura mortality. Moina inst. mortality: Moina micrura instant mortality. Brachionus mortality: Brachionus rubens mortality. Brach. inst. mortality: Brachionus rubens instant mortality.

* Significant at the level $p<0.05$.

** Significant at the level $p<0.01$.

*** Significant at the level $p<0.1$. 
Oocystis pusilla Hansg. 1890 was found to account for $99.5 \%$ of the phytoplankton biomass of the pond during the experiment. A minimal presence of other species such as Scenedesmus acuminatus (Lagerh.) Chod. 1902, Chlorococcum infusionum (Schrank) Menegh. 1842, Pandorina morum (O.F. Müller) Bory 1824 and Coelastrum microporum Näg. Un A. Br. 1855 was detected, but these were not considered in the counts. Fig. 2 shows the time-course for Oocystis pusilla biomass. At 18:30 h Oocystis biomass reached its maximum: twice the starting value in the first replicate and three times that initial value in replicates 2 and 3 . At time 0 Oocystis population consisted mainly of single cells, and only $2 \%$ were daughter cell colonies within the parental cell wall (the same percentage in all replicates). However, at the end of the experiment, $26 \%, 38 \%$ and $35 \%$ colonies were recorded for replicates 1, 2 and 3, respectively. Oocystis biomass showed significant correlation with temperature, $\mathrm{pH}$, unionised ammonia, Brachionus rubens mortality and Moina micrura mortality in each replicate experiment; correlation with dissolved oxygen was only noted in replicate 2 ( Table 1 ).

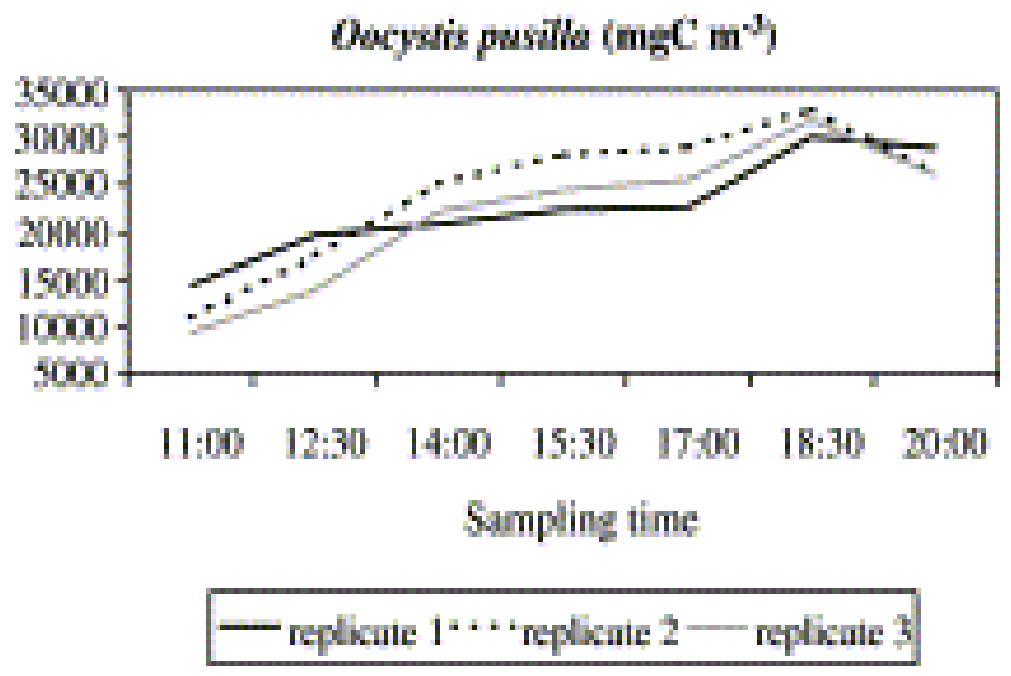

Fig. 2. Time-course shown by Oocystis pusilla biomass in the three replicate experiments.

$98 \%$ of the total zooplankton biomass in the pond during the study was composed of Moina micrura and Brachionus rubens. Further taxa present were Brachionus calyciflorus Pallas 1766 and small Ciliata.

The graphs in Fig. 3 show the changes over time for the variables corresponding to Moina micrura (living organisms, dead organisms, mortality and instant mortality). Initial mortality was less than $17 \%$ in all replicates. The mortality of Moina increased from 11:00 to 14:00 $\mathrm{h}$, but then remained stable until the end of the experiment. Mortality levels of $63 \%, 27 \%$ and $34 \%$ were recorded for replicates 1, 2 and 3, respectively. No further dead specimens were detected from 15:30 h until the end of the experiment. The number of living specimens fell to almost half in replicate 1 , but this mortality was compensated by growth in the other replicates. The highest instant mortality was recorded at 14:00 $\mathrm{h}$ in all the replicates but in the second and third replicates reached lower values than in the first one. 


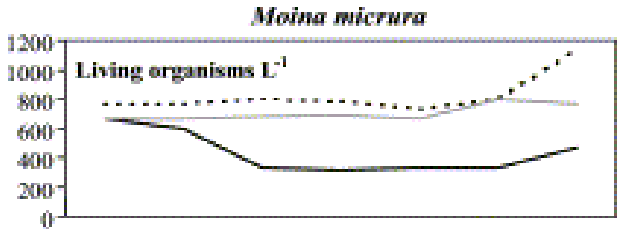

Fig. 3.

Time-courses shown by the number of living and dead organisms, mortality and instant mortality of Moina micrura in the three replicate experiments.
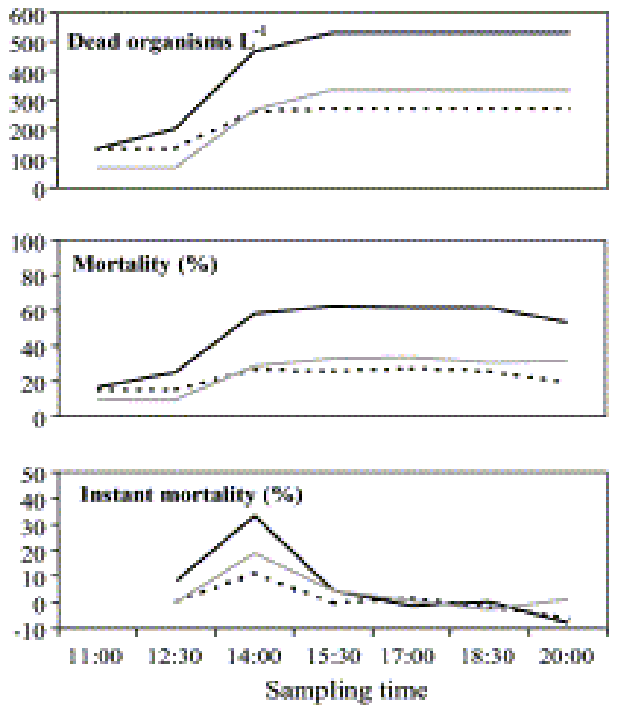

- replicate 1 $\cdots$ replicate 2 - replicate 3

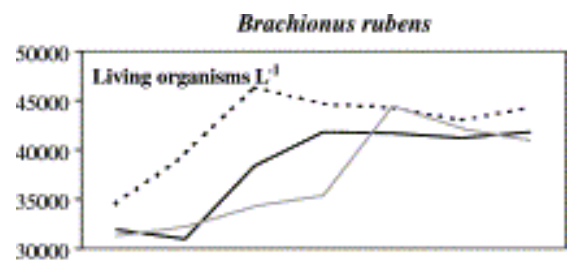

Fig. 4. shows the time-courses recorded for living specimens, dead specimens, mortality and instant mortality of Brachionus rubens. Initial mortality was lower than $0.4 \%$ in all replicates. In contrast to Moina, the mortality of Brachionus increased throughout each of the replicate experiments, although reaching moderate values: $7.3 \%$ in

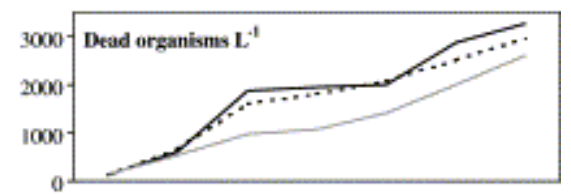
replicate $1,6.2 \%$ in replicate 2 and $6.0 \%$ in replicate 3 . Peaks in instant mortality were observed in all the replicates at 14:00 and 18:30 $\mathrm{h}$, but these were less pronounced in replicates 2 and 3 . In spite of mortality and due to the emergence of new organisms from eggs,

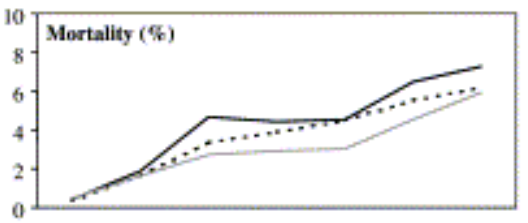
the density of living specimens rose during the experiment ( Fig. 4). The Brachionus population increased by some 10,000 specimens $\mathrm{L}^{-1}$ in each replicate.

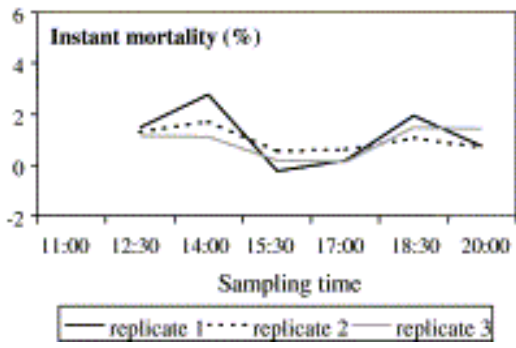

Fig. 4.

Time-courses shown by the number of living and dead organisms, mortality and instant mortality of Brachionus rubens in the three replicate experiments. 
Both Moina and Brachionus mortality showed significant correlation with unionised ammonia, $\mathrm{pH}$, temperature and Oocystis biomass, and between themselves in each of the replicates ( Table 1). The mortality rate of both species showed correlation with dissolved oxygen in replicates 1 and 2, yet dissolved oxygen was never limiting for population survival (see Section 4). No relationships worth mentioning were observed between instant mortality of Moina or Brachionus and the remaining variables. Time-lags of 90 and 180 min were tried in correlations between variables related to mortality and abiotic variables, but the number of data was low and the results showed higher significance without any time-lag.

\section{DISCUSSION}

Observations made on the experimental pond over the last 5 years have shown Moina micrura to be less adapted to this extreme ecosystem than Brachionus rubens: Moina was only significantly present during a few summer weeks, whereas Brachionus usually exhibited the highest biomass of the zooplanktonic community over most of the annual cycle (unpublished data). During the experiment, the Moina micrura population was more affected by unionised ammonia than the population of Brachiones rubens. Schlüter and Groeneweg [4] found that with an unionised ammonia concentration of up to $3 \mathrm{mg} \mathrm{N} \mathrm{L}^{-1}$, reproduction of Brachionus rubens in culture was unaffected; in the range 3-5 mg $\mathrm{N} \mathrm{L}^{-1}$, the reproduction rate decreased although no dead organisms were noted, yet at levels above $5 \mathrm{mg}$ $\mathrm{N} \mathrm{L}^{-1}$ the rotifers died within 2 days. During the second half of our experiment, unionised ammonia levels were very close to this lethal threshold reported for Brachionus. Nevertheless, the population showed a low mortality rate in spite of the high unionised ammonia concentration, and a considerable number of organisms were observed to emerge from eggs. In contrast, the possibility of Moina surviving this environmental pressure was small; in fact, the Moina population had disappeared from the pond 15 days after the experiment, while the Brachionus population remained stable (unpublished data). The levels of unionised ammonia which are harmful for Moina micrura had been scarcely reported in the literature until now. Jana and Chakrabarti [6] studied the life table responses of Moina micrura and Daphnia carinata to manure application in outdoor culture tanks monitored on a daily basis. These authors attributed the detrimental influence on life table and productive potentials of the cladocerans during the early phase of organic manures application to the environmental stress caused by reduction in primary production and excessively high values of ammonia concentration (ammonia levels of $0.47-0.48 \mathrm{mg} \mathrm{N} \mathrm{L}^{-1}$ ). An acute effect of unionised ammonia levels above $2.5( \pm 0.2) \mathrm{mg} \mathrm{L}^{-1}$ on Daphnia magna was reported in a compilation of several investigations made by the US EPA [9]. This reference is in agreement with our findings on Moina. In addition to these acute effects, chronic exposure to low levels of unionised ammonia can affect the structure and function of aquatic organisms [9]. A cyclic intra-daily transition from acute $\mathrm{NH}_{3}$ levels to lower levels, and vice versa, seems to be common in treatment ponds during the summer; so chronic toxic effects of lower levels of unionised ammonia should not be neglected.

It could be argued that other factors may have affected zooplankton dynamics during the assay, but apart from unionised ammonia, no further noxious factors were noted. There is clear evidence that cause-effect relationships exist between some variables, such as phytoplankton, $\mathrm{pH}$, unionised ammonia and dissolved oxygen. These dependence relationships could affect the interpretation of the correlations in Table 1 . Nevertheless, water temperature, $\mathrm{pH}$ and dissolved oxygen never exceeded the tolerance ranges described for Moina micrura [20] and [21] and Brachionus sp. [22], so it is reasonable to assume that the cause of zooplankton mortality can be attributed to $\mathrm{NH}_{3}$ toxicity.

The highest instant mortality rates were observed at 14:00 $\mathrm{h}$ for both species, coinciding with the highest temperature, $\mathrm{pH}$ and unionised ammonia concentration. However, no relationships worth mentioning were found between the instant mortality of each species and the remaining variables. The question which arises is, if un-ionised ammonia remained at a similar level from 14:00 $\mathrm{h}$ to the end of the experiment, why did instant mortality rates decay? The organisms might have been less tolerant during the periods when the 
$\mathrm{NH}_{3}$ concentration was quickly increasing (from 11:00 to 14:00 h) than when $\mathrm{NH}_{3}$ levels were high but stable (from 14:00 to 20:00 h; Fig. 1). In two species of trout, Thurston et al. [3] observed that fish were more tolerant of constant concentrations of ammonia than fluctuating concentrations. Similar responses might occur in zooplankton populations but further investigation in this area is required. Moreover, the genetic diversity of zooplankton populations could explain the variability of responses shown by different organisms (surviving capacity) under similar conditions of environmental stress.

Far from being negatively affected by unionised ammonia levels and zooplankton grazing, Oocystis pusilla increased significantly its biomass and the number of reproductive cells (colonies) formed from single cells. These findings are in line with field observations [10] made on phytoplankton on a longer timescale. Nevertheless, Abeliovich and Azov [23] observed toxicity effects at similar ammonia concentrations and $\mathrm{pH}$ values over 8 on Scenedesmus obliquus in a sewage oxidation pond (such as inhibition of photosynthesis and growth). A higher concentration of unionised ammonia would probably be needed to produce similar effects on Oocystis but this has yet to be confirmed.

Until now, no reference has been made in the literature to short-term (hourly) monitoring of natural zooplankton populations in treatment ponds, despite its relevance in understanding the processes operating on this time-scale and its influence on the pond performance. The present findings are in agreement with the hypothesis that attributes a decrease in zooplankton biomass during certain stratification periods (algal blooms) to a side-effect of an excess of phytoplankton biomass, which finally causes unionised ammonia to rise above the limits of toxicity [10] and [11]. Processes occurring on a short time scale promote plankton responses, the effects of which on the community dynamics may not be observed on longer time scales of monitoring. However, only on this "physiological time-scale" will it be possible to understand the ecological processes involved.

\section{CONCLUSIONS}

The zooplankton community of a deep waste treatment pond was exposed to the natural short-term fluctuations of unionised ammonia (90-min intervals of monitoring) that occur in the course of a day during a summer algal bloom. Moina micrura and Brachionus rubens were the most abundant species in the zooplankton community during the selected period. Three replicate experiments were conducted in which time-courses of water temperature, $\mathrm{pH}$, dissolved oxygen, total ammonia, unionised ammonia, phytoplankton biomass and zooplankton (number of living and dead organisms, mortality rate and instant mortality) were studied.

The behaviour of abiotic variables was similar in the three replicate experiments. The time-course of unionised ammonia concentration was consistent with those shown by temperature, $\mathrm{pH}$, Oocystis pusilla biomass, dissolved oxygen, Moina micrura mortality and Brachionus rubens mortality. Nevertheless, temperature, $\mathrm{pH}$ and dissolved oxygen never exceeded the tolerance ranges described for Moina and Brachionus, which led us to attribute the cause of zooplankton mortality to $\mathrm{NH}_{3}$ toxicity.

The Moina micrura population attained a mean mortality rate of $41.3 \%$. The highest instant mortality was recorded at 14:00 $\mathrm{h}$.

Brachionus rubens increased its population by around 10,000 organisms $\mathrm{L}^{-1}$ during the experiment. Brachionus mortality increased from the start to the end of the experiment, but only $6.5 \%$ of the population was affected. Instant mortality peaks were observed at 14:00 and 18:30 $\mathrm{h}$.

Oocystis pusilla biomass increased during the experiment. A $31 \%( \pm 5 \%)$ increase in the number of colonies with respect to single cells was also observed. Oocystis growth, far from being negatively affected by the unionised ammonia levels reached in the water, seemed to be enhanced. 
These results on a short time-scale of monitoring confirm previous field observations [10] and [11] that attributed reductions in zooplankton biomass during certain periods of summer stratification (algal blooms) to a side-effect of an excessive increase in phytoplankton biomass. These phytoplankton blooms, in turn, cause the unionised ammonia concentration to rise above a threshold that poses a risk for aquatic organisms.

\section{ACKNOWLEDGEMENTS}

This research was funded by the Comunidad de Madrid (07M/0060/1998).

\section{REFERENCES}

J.S. Alabaster, R. Lloyd

Water quality criteria for freshwater fish Butterworths, London (1980)

J.R. Karr, R.C. Heidinger, E.H. Helmer

Effects of chlorine and ammonia from wastewater treatment facilities on biotic integrity

J Water Pollut Control Fed, 57 (9) (1985), pp. 912-915

R. Thurston, C. Chakoumakos, R. Russo

Effect of fluctuating exposures on the acute toxicity of ammonia to rainbow trout (Salmo gairdneri) and cutthroat trout (S. clarki)

Water Res, 15 (1981), pp. 911-917

M. Schlüter, J. Groeneweg

The inhibition by ammonia of population growth of the rotifer, Brachionus rubens, in continuous culture

Aquaculture, 46 (1985), pp. 215-220

J.P. Yu, K. Hirayama

The effect of un-ionized ammonia on the population growth of the rotifer in mass culture Bull Jpn Soc Sci Fish, 52 (9) (1986), pp. 1509-1513

\section{B.B. Jana, R. Chakrabarti}

Life table responses of zooplankton (Moina micrura Kurz and Daphnia carinata King) to a manure application in a culture system

Aquaculture, 117 (1993), pp. 273-285

G.T. Ankeley, M.K. Schubauer-Berigan, P.D. Monson

Influence of $\mathrm{pH}$ and hardness on toxicity of ammonia to the amphipod Hyalella azteca

Can J Fish Aquat Sci, 52 (1995), pp. 2078-2083

D.P. Monda, D.L. Galat, S.E. Finger

Evaluating ammonia toxicity in sewage effluent to stream macroinvertebrates: I. A multilevel approach

Arch Environ Contam Toxicol, 28 (1995), pp. 378-384

US EPA. 1999 update of ambient water quality criteria for ammonia. EPA-822/R-99-014. Washington, DC: Off. Water, 1999. 
Arauzo M.

Harmful effects of un-ionised ammonia on the zooplankton community of a deep wastewater self-regeneration pond. Water Res 2003;37(5):1048-54.

The role of algae in a deep wastewater self-regeneration pond Water Res, 34 (14) (2000), pp. 3666-3674

D.A. Matthews, S.W. Effler, C.M. Matthews

Ammonia and toxicity criteria in polluted Onondaga lake, New York

Water Environ Res, 72 (6) (2000), pp. 731-741

Arauzo M.

(Madrid): su dinámica en relación a

diferentes escalas temporales. Ph.D. thesis, Universidad Autónoma de Madrid, Madrid, 1992.

M. Arauzo

Biotic and abiotic features of a deep wastewater treatment lagoon used for agricultural irrigation

Water Environ Res, 72 (2) (2000), pp. 243-247

H. Utermöhl

Zur Vervollkomnung der quantitativen Phytoplankton-Methodik

Mitt Internat Ver Limnol, 9 (1958), pp. 1-38

E.A. Rott

Some results of phytoplankton counting intercalibrations

Schweiz Z Hydrol, 43 (1) (1981), pp. 34-62

H.J. Dumont, I. van del Velde, S. Dumont

The dry weight estimate of biomass in a selection of Cladocera, Copepoda and Rotifera from the plankton, periphyton and benthos of continental waters

Oecologia, 19 (1) (1975), pp. 75-97

APHA. Standard methods for the examination of water and wastewater. Washington, DC: American Public Health Association, 1989.

StatSoft, Inc. Staff. Quick Statistica for Windows. Stat Soft, Incorporated. Tulsa, OK, 1995. $1000 \mathrm{pp}$.

Alonso M.

Ph.D. thesis, Universidad de Barcelona, Barcelona, 1985.

Gauthier H.

Essai sur le , le déterminisme du sexe et le réproduction de quelques

Moina (Cladocéres) récoltées en Afrique et á Madagascar. Minerva, Algiers, 1954. 
T. Nogrady, R.L. Wallace, T.W. Snell

Rotifera. Vol. 1: Biology, ecology and systematic SPB Academic Publishing, The Hague, The Netherlands (1993)

A. Abeliovich, D. Azov

Toxicity of ammonia to algae in sewage oxidation pond

Appl Environ Microbiol, 31 (6) (1976), pp. 801-806 